\title{
Effect of khat on ovarian oxidative stress in female rats
}

\author{
Nadia M. S. Arafa ${ }^{1 \& 2^{*}}$; Zahra Essa Ali Al sabi ${ }^{1}$ and Khaja Hafiz Faqihi ${ }^{1}$ \\ 1-Faculty of Science, Biology Department, Jazan University, KSA \\ 2-National Organization for Drug Control and Research, Department of \\ Physiology.nadianeuro@yahoo.com
}

\begin{abstract}
Oxidative stress (OS) greatly influences the reproductive health in female mammalian animals. The study used femaleWistar rats weighing $200 \pm 10 \mathrm{~g}$ grouped and administered orally as, control groups $(1 \mathrm{ml} \mathrm{CMC}),(0.5 \mathrm{~g} / 100 \mathrm{ml}$ carboxy methyl cellulose $))$ and Khat groups $(1 \mathrm{ml}$ khat extract) $(150 \mathrm{mg} / \mathrm{kg})$ each for 3 and 6 weeks. Ovaries from each group at the two experimental periods used for the determination of ovarian OS markers. Results showed significant decrease in superoxide dismutase (SOD) enzyme activities and nitric oxide (NO) levels and reduced glutathione/oxidized glutathione (GSH/GSSG) levels as well as significant increase in malondialdehyde (MDA) contents in khat groups after 3 and 6weeks of treatment as compared to their corresponding control values. Results overt that ovaries from rats subjected to khat extract were under OS due to the imbalance between ROS production and anti-oxidants.
\end{abstract}

Key words: Khat; Rat; Superoxide Dismutase; Nitric Oxide; Glutathione; Malondialdehyde.

\section{INTRODUCTION}

Khat (Catha edulis Forsk) is an evergreen bush that can grow to the height of an oak tree in the wild. The leaves are shiny and leathery, with serrated edges; the young leaves are light green and turning dark reddish green with age (Balint et al., 2009; Cox and Rampes 2003; Getahun and Krikorian, 1971).Millions of people use fresh leaves of Khat as a recreational drug on daily bases for its euphoric and psychostimulant effect. Khat leaves are chewed slowly over several hours, and the juice of the masticated leaves is swallowed as part of deep-rooted socio-cultural tradition of the indigenous population living in East Africa and the Arabian Peninsula (Al-Hebshi and Skaug, 2005; Belew et. al., 2000; Patel, 2015). The active stimulant ingredients of fresh khat leaves are cathinone and cathin and when its leaves dry, cathinone, the more potent converts to cathin, the less potent substance (Belewe et al., 2000; AlMotarreb et al., 2002).

Jazan region of Saudi Arabia lies at the far southwestern corner of the country and is adjacent to Yemen, where many types of khat trees are grown and where the prevalence of khat chewing is high (82\% among men and $43 \%$ among women) (Numan, 2004).

Detailed studies on the effects of khat on female reproductive activity are limited. The available data reveal that chewing of khat has a negative impact during pregnancy and on fetal growth or lactation (Bedada and Engidawork, 2010; kedir et al., 2013; Mwenda et al., 2003).In addition to previous studies that addressed the adverse effects of khat consumption or its active ingredient cathinone on male reproductive performance (Al-Habori, 2005, Dalu, 2000; El-Shoura et. al., 1995; Islam et. al., 1990;Mwenda et al., 2003). Many cross sectional studies performed to elucidate the prevalence of khat chewing among Jazani people and recorded the starting chewing khat during the age range 14-24 years, without neglecting that started less than 15 years old. They recorded chewing motivation was for fun (Ageely, 2009; Al-Sanosy, 2009; Alsanosy et al., 2013; Ayano et al., 2019; Mahfouz 


\section{Nadia M. S. Arafa et al.}

et al., 2015;Sheikh et al., 2014). They recorded use of Khat trend is increasing among higher education students in Jazan region. The prevalence of khat chewing was $33.2 \%$ and was significantly higher for males $42.2 \%$ than for females $11.3 \%$ (Mahfouz et al., 2015). The prevalence of chewing khat in this sensitive age range that characterized by the construction of personality and good health as well a period of fertility and giving future healthy generation. Islam religion educates his followers to keep away from everything that hurts their bodies, their lives and their souls and encourage them for benefits. Hence the use of khat through females with regard to the previously recorded health deleterious effects encourage research on the field of effect of chewing khat on female reproductive system to investigate.

Oxidative stress exerted by imbalance between productions of reactive oxygen species (ROS) and the biological system's capacity to detoxify the reactive intermediates or repair damage. This imbalance leads to the production of peroxides and free radicals that damage all components of the cell, including proteins, lipids, and DNA. (Deavall et al., 2012). Oxidative stress and production of ROS was identified to play a key role in the pathogenesis of subfertility in both males and females (Agarwal et al., 2012). The role for antioxidants and ROS in the ovarian environment and female fertility and subfertility is an area deserving research (Ruder et al., 2008).

This study designed to investigate the effect of oral Khat extract administration for 3 and 6 weeks on the oxidative stressstatus in rat's ovaries through the determination of the ovarian OS markers, MDA, GSH/GSSG, NO (nitrite/nitrate) in addition to SOD enzyme activity.

\section{MATERIALS AND METHODS Extraction of Khat (Catha edulis Forsk):} Extraction carried out by modification to the method (Harbone, 1984). One $\mathrm{kg}$ of Khat (Catha edulis Forsk) leaves was minced and macerated in 2.5 liter of $80 \%(\mathrm{v} / \mathrm{v})$ aqueous ethanol for 48 hours at room temperature with shaking. The supernatant was filtrated through a filter paper $(0.45 \mu \mathrm{m})$. This process was repeated two times in the same conditions. The extracts were collected, filtered and dried at room temperature. It was then weighed and the yield percentage (\% of dry weigh) was determined to be $10 \%$. The plate extract was then be refrigerated until use.

\section{Experimental animals:}

The study used twenty-four female albino rats (Rattus norvejicus), weighing $200 \pm 10 \mathrm{~g}$ and housed in plastic cages, kept under controlled temperature of $25 \pm 2$ OC and $12 \mathrm{~h}$ light / $12 \mathrm{~h}$ dark cycle throughout the experiment. The animals allowed adapting to the laboratory conditions for one week before the beginning of the experiment. Commercial rodent pellet diet and water were available ad libitum. Animals divided into two equal groups as follows:

1- Control groups (C3w and $\mathrm{C} 6 \mathrm{w})$ : administered $1 \mathrm{ml} \mathrm{CMC}(0.5 \mathrm{~g} / 100 \mathrm{ml}$ carboxymethylcellulose) P.O. daily for 3 and 6 weeks.

2- Khat groups (Khat $3 \mathrm{w}$ and Khat $6 \mathrm{w}$ ): administered $1 \mathrm{ml}$ P.O. daily dose of $150 \mathrm{mg} / \mathrm{kg}$ khat extract suspended in CMC for 3 and 6 weeks. Dose selection based on overdose of the average daily khat chewers $(500 \mathrm{mg} / \mathrm{kg}$ of dry plant) (Al-Hashem et al., 2011).

\section{Tissue samples preparation and biochemical assays}

Animals from control and treated groups the day after completion of eachperiod of treatment sacrificed and the 


\section{Effect of khat on ovarian oxidative stress in female rats}

ovaries excised from each animal, cleaned, dried and weighed. Each ovary homogenized in 1/10 weight/volume of $75 \%$ aqueous HPLC grade methanol. The homogenate was centrifuged at $4000 \mathrm{rpm}$ for $10 \mathrm{~min}$ and the supernatant used for application to High-Performance Liquid Chromatography (HPLC) analysis in sample volume application $20 \mu \mathrm{l}$. Each ovary sample will use for determination of the ovarian OS markers, malondialdehyde (MDA), reduced glutathione (GSH), oxidized glutathione (GSSG), nitric oxide (nitrite/nitrate) by HPLC as described in our previous studies and the chromatographic separation of reference standard and sample example illustrated in Figure (1)(Arafa et al., 2010, Rawi et al., 2011).Inaddition to superoxide dismutase (SOD) enzyme activity using spectrophotometric kits according to Nishikimi et al. (1972).

\section{Statistical analysis:}

Data expressed as means \pm SE. Statistical analysis evaluation by one-way analysis of variance (ANOVA) with LSD post hoc test and comparisons performed to assess the significance of differences among various groups at $p<0.05$ using IBM SPSS Statistics for Windows, Version 22.0. Armonk, NY: IBM Corp.

\section{RESULTS}

Data recorded in Table (1) showed very high significant effect between means of all groups for each recorded parameter, SOD, MDA, NO and GSH/GSSG. In addition to data represented in Figure (2) revealed significant decrease in SOD enzyme activities, NO and GSH/GSSG in treated groups for 3 and 6weks periods as compared withtheir corresponding normal control values. They recorded percentage changes from control values, (-26.86 and 20.30) for SOD, (-45.15 and -53.36) for $\mathrm{NO}$ and -22.22 and 23.53) for GSH/GSSG at 3 and 6 weeks intervals, respectively. On the contrary, data about MDA showed significant increase in treated groups throughout the experimental periods as compared withthe corresponding control values and verified percentage changes from control values, (42.11and 75.47) after 3 and 6 weeks of treatment, respectively.

Table (1): Effect of khat extract administration for 3 and 6 weeks in female albino rats on the ovarian OS markers.

\begin{tabular}{l|cccc}
\hline Groups & SOD $(\mathbf{U} / \mathbf{g})$ & MDA $(\mathbf{n g} / \mathbf{g})$ & NO $(\boldsymbol{\mu g} / \mathbf{g})$ & GSH/GSSG $(\boldsymbol{\mu g} / \mathbf{g})$ \\
\multicolumn{1}{c|}{ Parameter } & $188.67 \pm 6.54^{\mathbf{a}}$ & $0.57 \pm 0.03^{\mathbf{a}}$ & $6.60 \pm 0.28^{\mathbf{a}}$ & $0.18 \pm 0.005^{\mathbf{a}}$ \\
Khat 3w & $138.00 \pm 7.28^{\mathbf{b}}$ & $0.81 \pm 0.05^{\mathbf{b}}$ & $3.62 \pm 0.16^{\mathbf{b}}$ & $0.14 \pm 0.001^{\mathbf{b}}$ \\
C6w & $167.50 \pm 5.44^{\mathbf{c}}$ & $0.53 \pm 0.03^{\mathbf{a}}$ & $6.84 \pm 0.35^{\mathbf{a}}$ & $0.17 \pm 0.01^{\mathbf{a}}$ \\
Khat 6w & $133.50 \pm 7.45^{\mathbf{b}}$ & $0.93 \pm 0.07^{\mathbf{b}}$ & $3.19 \pm 0.18^{\mathbf{b}}$ & $0.13 \pm 0.01^{\mathbf{b}}$ \\
F (p) & $14.94^{*}$ & $15.790^{*}$ & $57.440^{*}$ & $15.548^{*}$ \\
\hline
\end{tabular}

Data expressed in mean $\pm \mathrm{SE}(\mathrm{N}=6)$ and compared by $\mathrm{F}$ test (ANOVA) using Post Hoc Test (LSD) for comparison between groups. The different superscripts are significant* at $\mathrm{p} \leq 0.05$. 
Nadia M. S. Arafa et al.

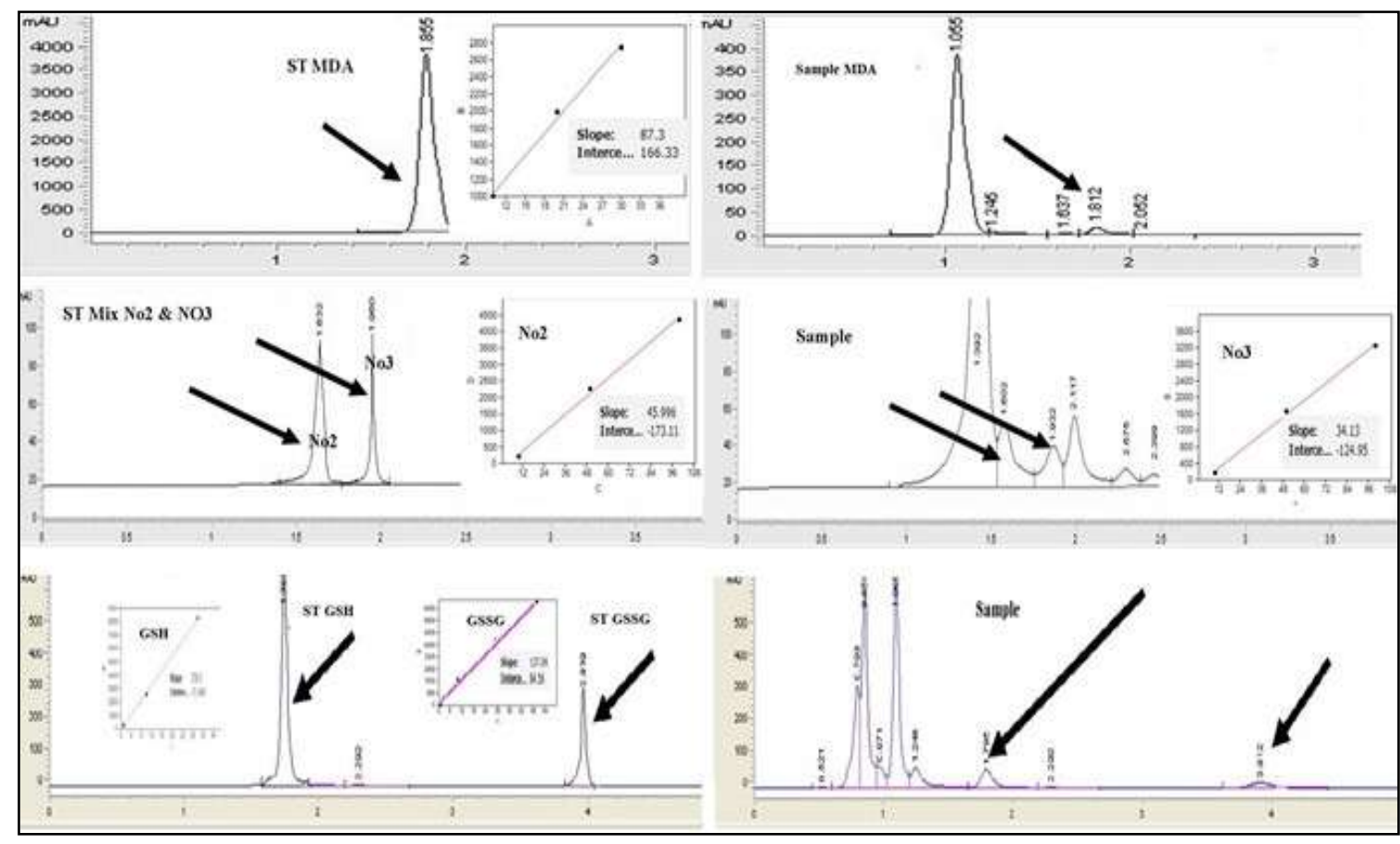

Fig. (1): HPLC Chromatogram of MDA, Nitrit, Nitrate, GSH and GSSG reference standards and sample examples.

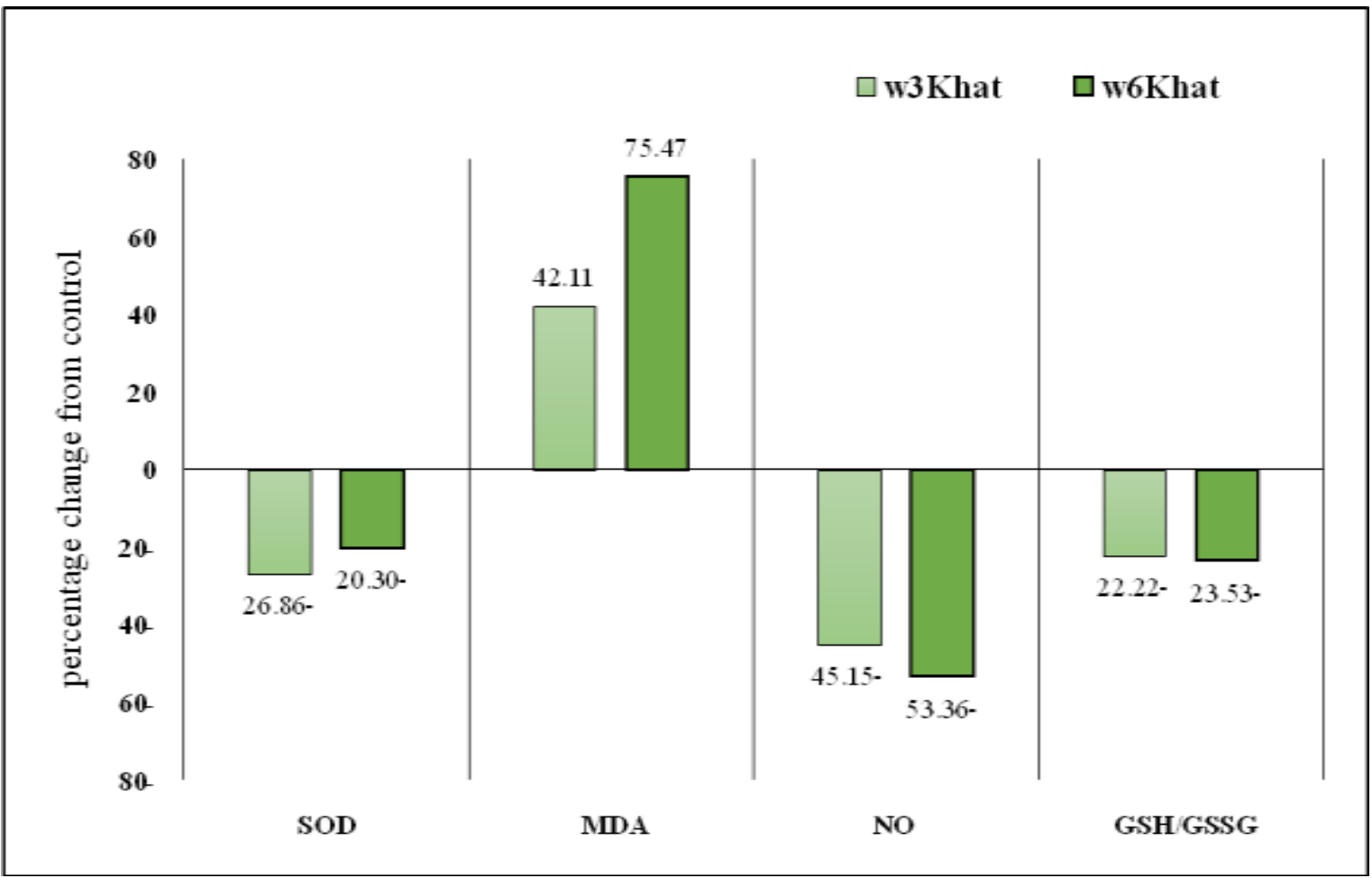

Fig. (2): Effect of khat extract administration for 3 and 6 weeks on the percentage changes from control value of the recorded OS markers, SOD, MDA, NO and GSH/GSSG ratio in rat ovarian tissue. 


\section{Effect of khat on ovarian oxidative stress in female rats}

\section{DISCUSSION}

Oxidative stress and production of ROS as pro-oxidant molecules may causereductionin the antioxidant defense mechanisms of the body and identified to play a key role in the pathogenesis of subfertility in both males and females (Agarwal et al., 2012).

In the present study, results revealed significantly decreased SOD enzyme activity throughout the experimental periods, indicating the consumption of this antioxidant enzyme against the overproduction of the free radicals, and catalyzed the dismutation of superoxide radical into hydrogen peroxide $\left(\mathrm{H}_{2} \mathrm{O}_{2}\right)$ and molecular oxygen $\left(\mathrm{O}_{2}\right)$ (Ighodaro and Akinloye, 2018). In addition, Sabatini et al. (2000) demonstrated that the SOD activity in follicular fluid from polycystic ovarian syndrome infertile women is significantly lower than that in proven fertility; suggestedthe role of SOD in the pathophysiology of the ovary. On the other hand, previous studies usingmicemodels with deletions of antioxidant genes reported that ovaries of adult female mice had reduced numbers of preovulatory follicles and corpora lutea and they were subfertile because of a defect in late follicular development or ovulation (Matzuk et al., 1998; Devine et al., 2011; Arianmanesh et al., 2011).

Moreover, MDA is the final degradation product of membrane proteins during OSand only index for lipid peroxidation but its interaction with DNA and proteins has often been referred to as potentially mutagenic (Del Rio et al., 2005) and reflects the degree of cell injury (Sharma 2004) as observed in ovarian elevated level of MDA in epithelial ovarian cancer (Caglayan et al., 2017).As regard to MDA in our study there were significant increases in MDA contents of 3 and 6 weeks treatment compared with the corresponding control In addition, ovarian NO level showed significant decreases in
Khat treated groups as compared to the corresponding control.. Nitric oxide is one of intraovarian mediators with possible effects in the ovulatory process and in the regulation of corpus luteum function (Zackrisson et al., 1996). Ovulation involves several biochemical pathways, which induce breakdown of extracellular matrix in the follicle wall with changes in the vasculature with evidenced role of NO in follicular rupture (Shukovski and Tsafrin, 1994; Bonello et al., 1996). Besides, direct effect of NO in ovulation at the ovarian level predicted by NO inhibitor reduced ovulation rate in in vitro rat ovary (Bonello et al., 1996). In addition to the demonstrated NOS mRNA in the rat ovary with maximal amounts of eNOS mRNA were present in the ovary at a time just prior to ovulation (Van Voorhuis et al, 1995). In addition, many sensory neurons projecting to the ovary contain NOS and release NO that, may participate in modulation of ovarian function in human, rats, and the circulating NO metabolites (nitrite and nitrate) observed to increase during follicular development (Rosselli et al, 1994).

Glutathione referred to as scavenging antioxidants from the second line defense antioxidants, which scavenge or neutralize free radicals to inhibit chain initiation and break chain propagation reactions (Ighodaro and Akinloye, 2018). The ratio of reduced glutathione (GSH) with oxidized glutathione (GSSG) (GSH/GSSG) often used as a marker of OS within cells(Locigno and Castronovo, 2001; Townsend et al., 2003). Our results indicated the significant decrease of the redox status showed by the ratio GSH/GSSG in ovarian tissues in Khat extract administered rats throughout the experimental periods.Normally the GSH/GSSG ratio exceeds 100/1, while in several models of OS this ratio decreased to values of 10:1 and even 1:1 (Chai et al., 1994). Glutathionelevels change rapidly during progression of meiosis and early 


\section{Nadia M. S. Arafa et al.}

embryonic development of oocytes, and its high content at the time of fertilization is essential for male pronucleus formation and for embryonic development to the blastocyst stage. Previous study by Devine et al. (2011)suggested that OShad significant negative impacts on female fertility and gamete health.Recently, Ramadan et al. (2017) reported that ROS and antioxidant enzyme systems involved in the regulation of reproductive processes, including ovarian follicular development, luteal steroidogenesis, endometrial receptivity and shedding, embryonic development and implantation, in addition to the role of oxidant-antioxidant status in epithelial ovarian cancer (Caglayan et al., 2017).

Khat toxicity recorded decreased activity of antioxidant enzymes due to ROs and OS in rats (Al- Qirim et al., 2002; Al-Zubairi et al., 2003), implicated by generation of free radicals despite of its present antioxidants as active ingredients (Al- Qirim et al., 2002; Al-Akwa et al., 2009; Aleryani et al., 2011; Al-Hashem et al., 2011) anddepletedantioxidant defense mechanisms in cells required for its optimal activity causing oxidative damage (shewamene and Engidawork, 2014).

On the other hand, Khat extract prolonged exposure in mice induced total and partial sterility in male and postimplantation loss in female and reduced the percent pregnancy rates (Tariq et al., 1986) and interacts with DNA metabolism as a potent genotoxic agent.(Abderrahman and Modallal, 2008).

\section{Conclusion:}

Results of this study suggested thatkhat extractexperienced ovarian OS status in rats.

\section{Acknowledgment:}

The author would like to acknowledge the Deanship of Scientific Research at Jazan University (Saudi Arabia) for the financial support under grant no. FR6-17.The authors also acknowledgeSubstance Abuse Research Center (SARC) for preparation of khat methanolic extract.

\section{REFERENCES}

Abderrahman, S.M. and Modallal, N. (2008). Genotoxic effects of catha edulis (khat) extract on mice bone marrow cells. JJBS, 1(4): 165-172.

Agarwal, A.; Aponte-Mellado, A.; Premkumar, B. J.; Shaman, A. and Gupta, S. (2012). The effects of oxidative stress on female reproduction: a review. Reprod. Biol. Endocrinol., 10: 49.

Ageely, H.M. (2009). Prevalence of Khat chewing in college and secondary (high) school students of Jazan region, Saudi Arabia. Harm. Reduct. J., 6:11.

Al Motarreb, A.; Baker, K.; Broadley, K.J. (2002). Khat: pharmacological and medical aspects and its social use in Yemen. Phytother. Res., 16: 403-413.

Al-Akwa, A.A.; Shaher, M.; Al-Akwa, S. and Aleryani, S.L. (2009). Free radicals are present in human serum of Catha edulis Forsk (Khat) abusers. J. Ethnopharmacol, 125(3):471-473.

Aleryani, S.L., Aleryani, R.A., Al-Akwa, A.A. (2011). Khat a drug of abuse: roles of free radicals and antioxidants. Drug Test Anal., 3(9):548-551.

Al-Habori, M. (2005). The potential adverse effects of habitual use of Catha edulis (khat). Expert Opinion on Drug Safety, 4(6), 1145-1154.

Al-Hashem, F.H.; Bin-Jaliah, I.; Dallak, M.A.; Nwoye, L.O.; Al-Khateeb, M. and Sakr, H.F. (2011). Khat (Catha edulis) extract increases oxidative stress parameters and impairs renal and hepatic functions in rats. Bahrain Med. Bull., 33:1-9.

Al-Hebshi, N.N., and Skaug, N. (2005). Khat (Catha edulis)-an updated 


\section{Effect of khat on ovarian oxidative stress in female rats}

review. Addiction Biol., 10(4): 299-307.

Al-Qirim, T.M.; Shahwan, M.; Zaidi, K.R.; Uddin, Q. and Banu, N. (2002). Effect of khat, its constituents and restraint stress on free radical metabolism of rats. $\mathbf{J}$ Ethnopharmacol., 83(3): 245-250.

Alsanosy, R.M.; Mahfouz, M.S. and Gaffar, A.M. (2013). Khat chewing among students of higher education in Jazan region, Saudi Arabia: prevalence, pattern, and related factors. BioMed. Res. Int., 2013, 487232.

Alshagga, M.A.; Alshawsh, M.A.; Seyedan, A.; Alsalahi, A., Pan, Y.; Mohankumar, S.K.; Alkebsi, A.; Kassim, S. and Mohamed, Z. (2016). Khat (Catha edulis) and Obesity: a scoping review of animal and human studies. Ann. Nutr. Metab., 69: 200-211.

Al-Zubairi, A.; Al-Haborim M.; Al-Geiry, A. (2003). Effect of Catha edulis (khat) chewing on plasma lipid peroxidation. J Ethnopharmacol, 87(1):3-9.

Arafa, N.M.S.; Salem, S.M. and Farid, O.A.H. (2010). Influence of Echinacea Extract pre-or postnatal supplementation on immune and oxidative status of growing rabbits. Ital. J. Anim. Sci., 9:e63-3: 338343.

Arianmanesh, M.; McIntosh, R.H.; Lea, R.G.; Fowler, P.A. and Al-Gubory, KH. (2011). Ovine corpus luteum proteins, with functions including oxidative stress and lipid metabolism, show complex alterations during implantation. J. Endocrinol., 210(1): 47-58.

Asrade, S., Shibeshi, W. Engidawork, E. (2013). Evaluation of the reversibility and possible mechanisms of antifertility of Catha edulis F. (khat) extract following subacute administration in rodents. AJPP, 7(40): 26932700.

Ayano, G.; Yohannis, K. and Abraha, M. (2019). Epidemiology of khat (Catha edulis) consumption among university students: a metaanalysis. BMC Public Health, 19(1): 150.

Balint, E.; Falkay, G. and Balint, G. (2009). Khat - a controversial plant. Wiener klinische Wochenschrift. The Middle Eur. J. Med., 121, 604-614.

Bedada, E. and Engidawork, E. (2010). The neuropsychopharmacological effects of Catha edulis in mice offspring born to mothers exposed during pregnancy and lactation. Phytother. Res., 24: 268-276.

Belewe, M.; Kassaye, M. and Enqoselassie, F. (2000). The magnitude of khat use and its association with health, nutrition and socio-economic status. Ethio. Med. J., 38: 11-26.

Bonello, N.; McKie, K.; Jasper, M.; Andrew, L.; Ross, N.; Braybon, E.; Brännström, M. and Norman, R.J. (1996). Inhibition of nitric oxide: effects on interleukin-1 betaenhanced ovulation rate, steroid hormones, and ovarian leukocyte distribution at ovulation in the rat. Biol. Reprod., 54(2):436-445.

Caglayan, A.; Katlan, D.C.; SelçukTuncer, Z.; Yüce, K.; Sayal, H.B.; Coşkun Salman, M. and Kocer-Gumusel, B. (2017). Impaired antioxidant enzyme functions with increased lipid peroxidation in epithelial ovarian cancer. IUBMB Life, 69(10):802-813.

Chai, Y.C.; Ashraf, S.S.; Rokutan, K.; Johnston, R.B.Jr. and Thomas, J.A. (1994). S-thiolation of individual human neutrophil proteins including actin by stimulation of the respiratory burst: evidence against a role for glutathione 


\section{Nadia M. S. Arafa et al.}

disulfide. Arch. Biochem. Biophys., 310: 273-281.

Cox, G. and Rampes, H. (2003). Adverse effects of khat: a review. Advances in Psychiatric Treatment. 9: 456463.

Dalu, A. (2000). Impact of long-term consumption of khat on public health. The Sudama Concern, 5: 15-16.

Deavall, D.G.; Martin, E.A.; Horner, J.M. and Roberts, R. (2012). Druginduced oxidative stress and toxicity. J. Toxicol., 645460.

Del Rio, D.; Stewart, A.J. and Pellegrini, N. (2005). A review of recent studies on malondialdehyde as toxic molecule and biological marker of oxidative stress. Nutr. Metab. Cardiovasc. Dis., 15(4): 316-328.

Devine, P.J.; Perreault, S.D. and Luderer, U. (2011). Roles of reactive oxygen species and antioxidants in ovarian toxicity. Bio. Reprod., 86(2): 27.

El-Shoura, S.M.; Abdel Aziz, M.; Ali, M.E.; El-Said, M.M.; Ali, K.; Kemeir, M.A.; Raoof, A.M.; Allam, M. and Elmalik, E.M. (1995). Deleterious effects of khat addiction on semen parameters and sperm ultrastructure. Human Reprod., 10(9): 2295-2300.

Getahun, A. and Krikorian, A.D. (1971). Coffee's rival from Harar, Ethiopia. I. Botany, cultivation and use. Economic Botany, 27 (4): 353377.

Harbone, J.B. (1984). Phytochemical Methods: A Guide to Modern Technique of Plant Analysis. (2nd ed). Chapman and Hall, London. pp. 1, 19: $37-168$.

Ighodaro, O.M. and Akinloye, O.A. (2018). First line defense antioxidants-superoxide dismutase (SOD), catalase (CAT) and glutathione peroxidase (GPX):
Their fundamental role in the entire antioxidant defense grid. AJM, 54: 287-293.

Islam, M.W.; Tariq, M.; Ageel, A.M.; AlFeraly, F.S. and Al-Meshal, I.A. (1990). An evaluation of the male reproductive toxicity of cathinone, Toxicology, 60(3):223-234.

Kamaludin, S.A.; El-setouhy, M.; Yagoub, U., Alsanosy, R. and Ahmed, Z. (2014). Khat chewing and health related quality of life: crosssectional study in Jazan region, Kingdom of Saudi Arabia. Health Qual Life Outcomes, 12:44.

Kedir, H.; Berhane, Y. and Worku, A. (2013). Khat chewing and restrictive dietary behaviors are associated with anemia among pregnant women in high prevalence rural communities in eastern Ethiopia. PLoS One, 8: e78601.

Locigno, R. and Castronovo, V. (2001). Reduced glutathione system: role in cancer development, prevention and treatment (review). Int. J. Oncol., 19: 221-236.

Mahfouz, M.S.; Rahim, B.E.; Solan, Y.M.; Makeen, A.M. and :lsanosy, R.M. (2015). Khat Chewing Habits in the Population of the Jazan Region, Saudi Arabia: Prevalence and Associated Factors. PloS one, 10(8): e0134545.

Matzuk, M.M.; Dionne, L.; Guo, Q.; Kumar, T.R. and Lebovitz, R.M. (1998). Ovarian function in superoxide dismutase 1 and 2 knockout mice. Endocrinol., 139(9):4008-40011.

Mwenda, J.M.; Arimi, M.M.; Kyama, M.C. and Langat, D.K. (2003). Effects of khat (Catha edulis) consumption on reproductive functions: a review. East Afr. Med. J., 80(6):318-323.

Nishikimi, M.; Roa, N.A. and Yogi, K. (1972). The occurrence of 


\section{Effect of khat on ovarian oxidative stress in female rats}

superoxide anion in the reaction of reduced phenazine methosulfate and molecular oxygen. Biochem. Biophys. Res. Commun., 46 (2): $849-854$.

Numan, N. (2004). Exploration of adverse psychological symptoms in Yemeni khat users by the Symptoms Checklist-90 (SCL-90). Addiction, 99(1): 61-65.

Patel, N.B. (2015). Natural Amphetamine Khat: A Cultural Tradition or a Drug of Abuse?. International Review of Neurobiology, 120: 235-255.

Ramadan, A.; Hemida, R.; Nowara, A.; Eissa, L.A. and El-Gayar, A.M. (2017). Role of oxidative stress in epithelial ovarian cancer in Egyptian patients. J. Exp. Ther. Oncol., 12(1):9-15.

Rawi, S.M.; Mourad, I.M.; Arafa, N.M.S. and Alazabi N.I. (2011). Effect of ciprofloxacin and levofloxacin on some oxidative stress parameters in brain regions of male albino rats. AJPP, 5(16):1888-1897.

Rosselli, M., Imthurm, B., Macas, E., Keller, P.J., Dubey, R.K. (1994). Circulating nitrite/nitrate levels increase with follicular development: indirect evidence for estradiol mediated NO release. BiochemBiophys Res Commun, 202(3):1543-1552.

Ruder, E.H.; Hartman, T.J.; Blumberg, J. and Goldman, M.B. (2008). Oxidative stress and antioxidants: exposure and impact on female fertility. Hum Reprod Update, 14(4): 345-357.

Sabatini, L., Al Shawaf, T., Wilson, C., Lower, A., Grudzinskas, J. G. (2000). Follicular fluid superoxide dismutase (SOD) activity in women with polycystic ovarian syndrome (PCOS). FertilSteril, 74(3): 253-254.

Safhi, M.M.; Alam, M.F.; Hussain, S.; Hakeem Siddiqui, M.A.; Khuwaja,
G.; JubranKhardali, I.A.; AlSanosi, R.M. and Islam, F. (2014). Cathinone, an active principle of Catha edulis, accelerates oxidative stress in the limbic area of swiss albino mice. J. Ethnopharmacol., 156: 102-106.

Sharma, S.; Kaur, R. and Sandhu, H.S. (2004). Effect of subacute oral toxicity of molybdenum on antioxidant status in cross bred cow calves. Ind. J. Anim. Sci., 74:734-736

Sheikh, K.A.; El-Setouhy, M.; Yagoub, U.; Alsanosy, R. and Ahmed, Z. (2014). Khat chewing and health related quality of life: crosssectional study in Jazan region, Kingdom of Saudi Arabia. Health and quality of life outcomes, 12: 44.

Shewamene, Z. and Engidawork, E. (2014). Subacute administration of crude khat (Catha edulis F.) extract induces mild to moderate nephrotoxicity in rats. BMC Complement Altern, Med., 14:66.

Shkolnik, K.; Tadmor, A.; Ben-Dor, S.; Nevo, N.; Galiani, D. and Dekel, N. (2011). Reactive oxygen species are indispensable in ovulation. Proc. Natl. Acad. Sci. U.S.A., 108: 14621467

Shukovski, L. and Tsafriri, A. (1994). The involvement of nitric oxide in the ovulatory process in the rat. Endocrinol., 135(5):2287-2290.

Tariq, M.; Al-Mesheal, I.A.; Parmars, N.S.; Ageel, A.M. and Qureshi, S. (1986). Evaluation of genotoxic potential of khat (Catha edulis) in Swiss Albino mice. Mutagenesis, 5: 381-382.

Townsend, D.M.; Tew, K.D. and Tapiero, H. (2003). The importance of glutathione in human disease. Biomed. Pharmacother., 57: 145155.

Van Voorhis, B.J.; Moore, K.; Strijbos, P.J.; Nelson, S.; Baylis, S.A.; 


\section{Nadia M. S. Arafa et al.}

Grzybicki, D. and Weiner, C.P. (1995). Expression and localization of inducible and endothelial nitric oxide synthase in the rat ovary. Effects of gonadotropin stimulation in vivo. J. Clin. Invest., 96(6): 2719-2726.
Zackrisson, U.; Mikuni, M.; Wallin, A.; Delbro, D.; Hedin, L. and Brännström, M. (1996). Cellspecific localization of nitric oxide synthases (NOS) in the rat ovary during follicular development, ovulation and luteal formation. Hum. Rreprod., 11(12): 2667-

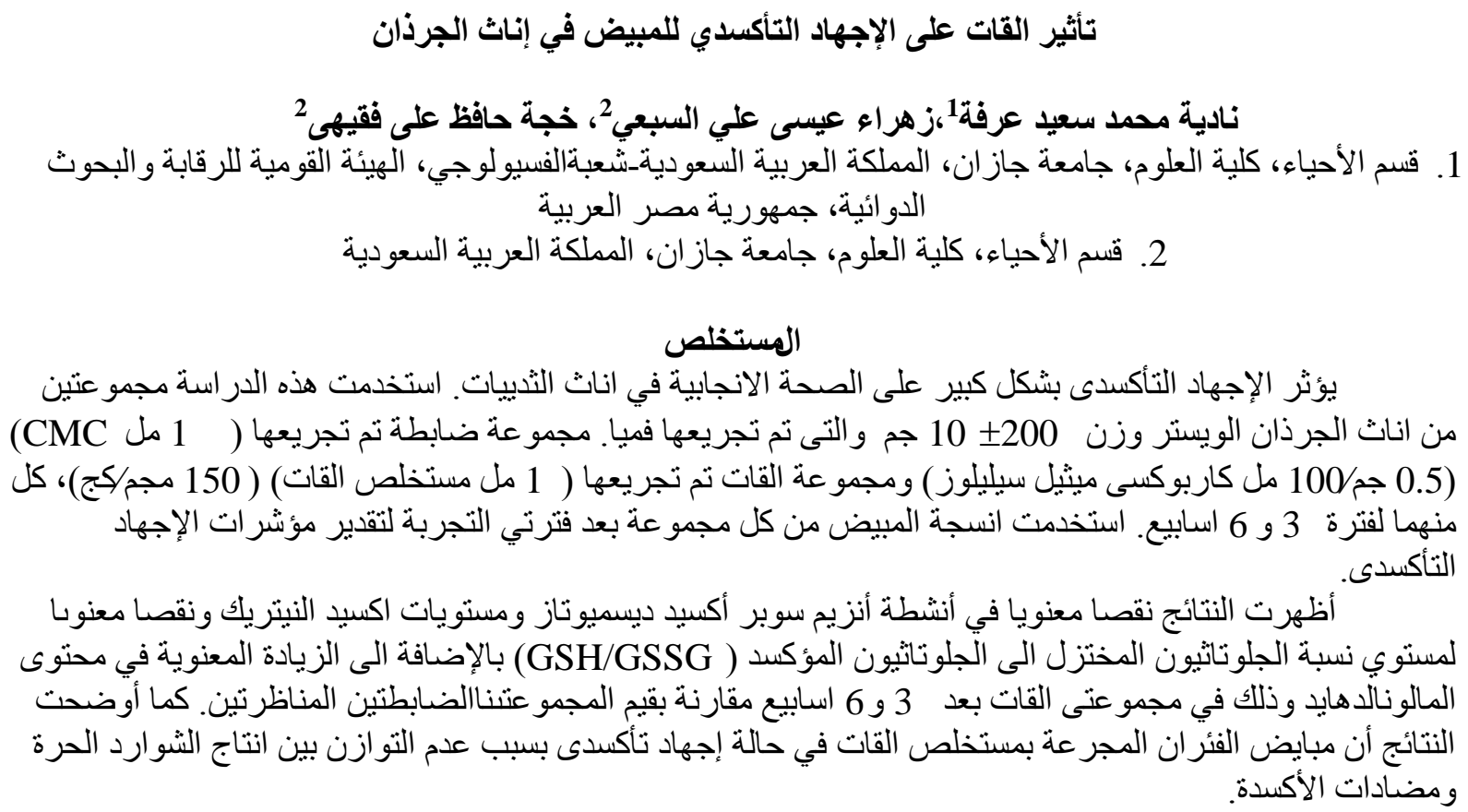

